\title{
Educational Model Study to Train and Develop Competitive Workers, Based on Learning Objectives
}

\author{
Ahmad Darmawi \\ Doctoral Student Community Empowerment Study Program, Sebelas Maret University, \\ Surakarta, Indonesia

\section{Darsono} \\ Faculty of Agriculture, Sebelas Maret University, Surakarta, Indonesia \\ Drajat Tri Kartono \\ Faculty of Social and Political Sciences, Sebelas Maret University, Surakarta, Indonesia
}

\author{
Sapja Anantanyu
}

Faculty of Agriculture, Sebelas Maret University, Surakarta, Indonesia

\begin{abstract}
Although training techniques are just right, learning cannot happen if the experience is not arranged properly. So, when drawing up a program of training and development, a very important set of learning stages during a training program or development and to provide the conditions that will sustain the performance in time. The descriptive method is used to search the fact with proper interpretation prior to implementing training programs, responsibility for learning and support the transfer of new behaviors. The content of the training program should be the same as the purpose of the lesson. Some types of learning objectives are the cognitive knowledge, technical skills or interpersonal, effective results, and ethical behavior.
\end{abstract}

Keywords: strategic interests, training, maximize learning, education

\section{INTRODUCTION}

Activities to train, develop and promotion of the worker is very closely connected, and such activities difficult, and perhaps impossible makes a clear distinction between those activities. In General, training practices and the development of a company is an effort that is indeed in deliberately to improve the performance of current and future by helping employees get the skills, knowledge, and attitudes that are in need to become a competitive workforce(Ameh et al., 2016; Bauerle, Brnich, \& Navoyski, 2016; R. Chen et al., 2014; Zumrah, 2015).

Typically, the training aims to improve performance in the short term and in a particular job by enhancing the competence of employees(Dasgupta, Suar, \& Singh, 2014; Tripathi \& Borrion, 2016). Most of the training for the knowledge and skills the work completed in just a matter of days. For existing employees, changes in technology, the loss of jobs in the hold, and the rearrangement of work can create the need for new job skills. Employees may also need new knowledge skills or because they are on the move or in promoting(Ameh et al., 2016; Kont \& Jantson, 2014). In some cases, employees require training to train back skills that not too often they use, as it is used only for the time of emergency.

Compared to the training efforts that focus on improving the short term, the development of activities that are intended to enhance the competence for the long term as the anticipation 
over the needs of the company in the come(Ye, Ye, \& Liu, 2018). Development activities can improve the performance in the work of someone, but that is not its primary goal(Bauerle et al., 2016). A common approach is actually in development is to give additional tasks to employees.

To enter a new job all employees must initially know the ins and outs. Through socialization or onboarding of new employees learn and see how work is done in a new environment(Dasgupta et al., 2014; Pomohaci, 2016; Wang, Lin, \& Tsay, 2016), including jobs that are not written in the policy or procedure book. Efforts to socialize employees usually occur during initial acceptance, but activities in mergers and acquisitions in companies or other major changes can also encourage socialization efforts.

When the target training is improving the performance of the work, the training should be designed with the use of information regarding job analysi of what is needed to do the job(Diaz-Vilela et al., 2015; FLOREA \& MIHAI, 2017). If the goal is to develop employees for promotion and progress in the days to come(Wang et al., 2016), then its activities must be suitable with the selection criteria to be used when receiving an employee in a higher position. If the goal of training is to create a culture change, it might be appropriate in linking performance evaluation and award on completion of the training.

Altogether, the job analysis and competency model to determine the tasks that are performed in an occupation and competence required for effective job performance(Fraser-Arnott, 2017; Grambow et al., 2017). Such information shall be the basis for the design of a training program ongoing to improve the performance of the work.

Training and development activities can be very expensive, takes time and money. Most of the expenses caused by employees who left his job and follow the training activity(Bauerle et al., 2016; FLOREA \& MIHAI, 2017; Wang et al., 2016). Perhaps the most important role of top executives is recognizing the value of training and investment in support of such activities. When a company starts to hold a philosophy of learning and continuous improvement(Badura et al., 2016; FLOREA \& MIHAI, 2017; Rangriz \& Pashootanizadeh, 2014), the more active participation in the preparation and delivery of training system of the company conducted by all companies is considered as an important and necessary.

\section{DETERMINE THE GOALS OF LEARNING}

Training program or development must have the same content as the lesson objectives. The General learning objectives usually include improved cognitive knowledge, develop skills, Affective response influence, and encourage ethical behavior(Marlos Varonis, 2014; Wang et al., 2016).

\section{Cognitive Knowledge}

Cognitive knowledge includes information that is owned by the employees, the way they operate such information, and their strategy for using the information(Astakhova, 2017; Ibenne, Simeonova, \& Harrison, 2017). These components are the kind of cognitive knowledge that try to overcome by companies through the training system.

Orientation program gives a short description to the employees about the benefits of the program and the options, inform about rules and regulations, as well as explaining the policies and practices of the company. This orientation programs inform new employees about the practices of the same job opportunities, safety, regulation of working time, rest time, 
composition as well as the history of the company, and possible product service companies(Atitumpong \& Badir, 2018; Kang \& Sung, 2017).

Training programs designed to improve basic skills deficiencies in grammar, mathematics, safety, reading, listening, and writing is still considered important for many companies today(Adjei \& Mensah, 2016). In particular, Total Quality Management (TQM) requires that the basic statistical knowledge of mathematics is still not controlled by the many graduates from high school. Many graduates of vocational high schools which still have deficiencies in these basic skills(G. R. Oliver, Lynch, Chadwick, Santini, \& Wilson, 2016; Ray, Milston, Doherty, \& Crean, 2017; Wongnaa \& Boachie, 2018).

The officers are being tried or are currently holding managerial positions may require knowledge of the structure of the company, the products, and services of the company, the company's business strategy, as well as the changing conditions in the work environment. Most of these types of knowledge learned through the granting of employment standards(Koch \& Fritz, 2013; Nissim \& De Vries, 2014) and development while learning experiences, such as working in the task force(Chukwuere, 2018; Sofiadin, 2014).

\section{Skills}

Skills-based learning usually involves practices behaviors that are expected, as the behavior demonstrated technical skills, interpersonal, or language(Anwaruddin, 2015; Heaysman \& Tubin, 2018). Because of rapid changes in technology and the nature of the work(Kruse \& Wilcox, 2015), as well as the use of an automatic Office, industrial, and managerial systems(Lin, 2005), update technology and the creation of skills being the main boost in training.

Skills in communication, conduct a performance assessment, team building, leadership, leadership(Fong et al., 2010; Gupta, Mehta, \& Sagar, 2015), and negotiation are increasingly needed. The development of interpersonal skills is vital for managers and middle-and lowerlevel employees who have a direct relationship with the community(Hall \& Hall, 2009; van Dyk \& Fourie, 2012).

\section{Affective outcomes}

When the desired result from socialization experience, training, or development is a change in motivation, attitudes, or values, learning objectives are Affective outcomes(Lee, Lim, \& Ng, 2008; Marjoribanks, 2006; Tomažič, Hummel, Schrenk, Rupnik, \& Randler, 2018). Training programs designed to enhance emotional intelligence officer is another example of efforts targeting Affective outcomes. emotional intelligence is the introduction and setting the emotions in oneself and others. This intelligence includes self-awareness, self-management, social awareness, and relationship management(Dewaele, 2019; Jan \& Anwar, 2019). One of the goals of the training emotional intelligence is taught techniques to deal with emotions in the workplace to employees.

\section{On the Job}

\section{SELECT THE FORMAT OF THE PROGRAM}

On the Job (0JT) takes place when employees learn about their work under direct domination. Trainees learn by observing experienced employees and work with materials, workers, or the actual machinery that underlies the work. An experienced officer is expected to coach can give a good example and set aside time from regular job responsibilities to provide instruction and guidance associated with the job. If the trainer is working in the same field, then the participants will receive feedback regarding performance directly. As described at the 
beginning of this chapter, OJT is very important to develop the skills of employees that work in any field(Grover \& Miller, 2019; Smith, 2002).

One of the advantages of this training was to transfer his training level is high(Komulainen \& Sannerud, 2018). Because the participants learn the skills in an environment where they will really work, they are ready to apply these skills in the improvements. On-site training, however not appropriate when only a handful of employees who must be trained and when the consequences of his ways. Furthermore, the quality of training depends on the ability of managers(Seyfried \& Pohlenz, 2018) or employees who administer it. OJT will be effective if designed carefully and considered to be a formal process for managing the performance of the work.

\section{On-Site, but not the OJT}

When the consequences of his error are high, usually fit better perform training off the job. Onsite training work indirectly on the job is very appropriate for the programs that are required after hours and programs in which the contact should be maintained with a work unit, but OJT will be disturbing or dangerous. Training is also suitable for voluntary programs(Lukuyu, Place, Franzel, \& Kiptot, 2012; Thompson \& Russell, 2017) after hours and programs that update the competence(Tomozeiu \& Kumpulainen, 2016) of employees while still allowing them to perform his normal duties.

\section{Off-Site}

training outside the company would be appropriate when an elaborate competence should be controlled(Forsblom, Negrini, Gurtner, \& Schumann, 2016) or when employees must focus on the particular interpersonal competence(Wubbels, Brok, Veldman, \& Van Tartwijk, 2006) does not appear evident in the ordinary working environment. Teamwork difficult ECE management was built if all team members continue to feel disturbed by call phone and subordinates. The team will be more easily in the wake time of retreat when all team members have the time to focus on the establishment of the relationship.

One disadvantage is the cost of this training is relatively high(Jung*, 2005). The cause for concern is the knowledge that is acquired outside of work cannot be transferred to the working environment. The problem of diversion of whether employees are ready to apply the knowledge and skills that have been studied training is one of the most important considerations when selecting a training format. Research shows that the training environment is different from the actual working environment. Therefore, participants will not be able to apply what they have learned in their work.

\section{Set The Stage of Learning}

\section{MAXIMIZE LEARNING}

Before carrying out the training program, the coach or manager must consider how information will be presented. In addition, they should consider beliefs about competence training for specific tasks(Sanli, Ennis, Brown, \& Carnahan, 2018). To perform as expected, employees need to know what to expect(Gorgievski, Bakker, \& Schaufeli, 2010). Clear instructions will form the right behavior expectations. Training expectations should be stated in specific terms(Daszuta \& Ghosh, 2018). The conditions under which the performance expected or unexpected must be identified, in line with the behavior that will be on a show. To set the desired performance stages, a gift set in advance because the performance as expected could be appropriate. The trainee will be more motivated if they know that a good performance can bring positive reinforcement(Rasmussen, Voelker, \& Eliasmith, 2017). 
To perform as expected, employees need to know what to expect. Clear instructions will form the right behavior expectations. Training expectations should be stated in specific terms. The conditions under which the performance expected or unexpected must be identified, in line with the behavior that will be on a show. To set the desired performance stages, a gift set in advance because the performance as expected could be appropriate. The trainee will be more motivated if they know that a good performance can bring positive reinforcement(Martinez, 2014; Van Looy \& Goegebeur, 2007).

Although the instructions were clear, expected behavior may still not happen if participants do not know how to carry out those instructions. This problem can be overcome by the behavior that would explain the behavior that will be studied to the trainee with a model that provides a visual demonstration of expected behavior(Hubert, Vrij, Horselenberg, van Koppen, \& AdamsQuackenbush, 2019; McCarley et al., 2006), allowing trainees to imitate the behavior, and giving criticism. The important thing is to demonstrate to employees what to do before asking them to do it. So the model must not only show how to achieve the desired results but also how to overcome obstacles.

\section{Enhance Learning During Training}

Although employees should be responsible for their own analytical study, companies can do many things to help them. Employees work better if they are actively involved in the learning process(Field, 2011; Poell \& Van Der Krogt, 2017). The company's assistance in this field can range from encouraging active participation in class discussions to help order the program that will assist managers in major strategic changes. Points to the importance of the individual in a learning associate are. Through active participation(Moyo, 2014), individuals remain more vigilant(van der Post, de Weerd, Verbrugge, \& Hemelrijk, 2013) and are more confident(Chua, Hannula, \& Ranganath, 2012; Whiteside, Garrett Dikkers, \& Lewis, 2017).

If the employee still lamenting its shortcomings, then difficulties others will look even more weight and looks. If the training fails to validate the experience of fear over failure, participants will feel less threatened and will further develop a sense of mastery. To assist in the mastery, the coach must compose the subject matter(Scott, Cortina, \& Carlisle, 2012) so that trainees experience a success(Sack, 2012). Although it can be very easy for simple tasks, it also can be very difficult if his duties complicated. The solution was to classify tasks, establish behavioural, and goal setting. Its task is to divide a complex task into component parts that are smaller or simpler. The formation behavior of utilizing the estimate closer to the expected behaviours, which when learning how to do the interview, the manager selection can be assisted to make eye contact and develop questions circumstantial. Man in the middle or proximal goal setting also increases the perception of mastery. Proximal goal itself is projected specifications meet deadlines.

For those who master the new concepts and gain new competencies(Covarrubias Venegas \& Thill, 2015), they should get accurate diagnosis feedback about their performance(Flores, Liew, Miner, Bench, \& Lench, 2015). Criticism or input can be assigned to supervisors, coworkers, customers, computer, or the person doing the work. Criticism or feedback should be specific(Marlow, 2016), timely, based on behavior and not the personalities, as well as practical(Lam, 2017). If there is a lack of rendering performance, such criticism must be also Diagnostics and pilot instruction or to work better.

The purpose of skills training is to ensure that the behavior is not only expected to happen once, but consistently. Consistency will happen when trainees are able to practice and improve standards of performance(Bennett, Tognolini, \& Pickering, 2012; Copella \& Sireci, 2013). Even 
mental practices can also improve performance. However, because of the wrong behavior of practicing a very disturbing, employees should get criticism specifically about his mistakes(Lewiński, 2017) to ensure that they only practice the proper behavior.

\section{Maintain Performance After Training}

After providing socialization, training, and development experience to the employees, the work environment must support the transfer of new behaviors(Wolff, 2015) to the workers and maintain it. The use of goals and strengthening can increase performance after training(Masset \& Haddad, 2015).

The absence of specific and measurable goals(Richey, Bernacki, Belenky, \& Nokes-Malach, 2018), employees have little basis for judging what they do. The specific purpose of performance after the training should be challenging, but not too hard so that it still can be accomplished. These goals also should not be set too early in the learning process. The development of specific action plans is one approach to goal setting that links what has been learned with the approach of the time.

Learn new behavior can be difficult(Wang et al., 2016) and dangerous. To ensure that participants continue to demonstrate the skills they have learned, the behavior must be strengthened. Reinforcement is a consequence that follows the behavior(Charles Catania, 2017). Reinforcement can be positive (for example, praise and financial rewards) or negative, but the consequences must be in accordance with the performance. Supervisors and coworkers can be taught to solidify the changes expected. If a supervisor or co-worker gave a positive response toward positive changes in behavior(Cohn \& Fredrickson, 2010; Erlandsson, Nilsson, \& Västfjäll, 2018), then the frequency behavior of the new show will increase.

Because the other person is not always may strengthen one's individual workers, the longterm goal should be to teach employees how to set their goals and carry out the reinforcement of their own. When creating an incentive for self-efforts(Jeffrey \& Adomdza, 2011), employees are able to create appropriate self-satisfaction with its performance. The challenge is ensuring that the same objectives with the objectives of the company thus creating self-management(De Vos, Dewettinck, \& Buyens, 2009).

\section{STRATEGIC TRAINING AND DEVELOPMENT OF EDUCATIONAL PROGRAMS}

It is important to improve training and development by an institution be it industrial corporations, educational institutions or other Community institutions so that the existence of training and development is able to improve the performance of creative will implies institutional reputation(Olokundun et al., 2018). However, most importantly, training and development will enhance the ability of the community in this program participants and community participants to obtain the necessary information, guidance, and support needed to learn, survive, graduation, and achieve their aspirations.

A training and development program has been established as a form of training is commonly used in the development of corporate identity ranging from employee performance appraisal process. The different academic approach, starting from the observation of the company with respect to the lack of competence of the graduates at the time the employee recruitment process. The Corporation indicated that training and development program as an alternative form of education in academics to get the desired competencies(Marinescu \& Toma, 2013). Training to become a very valuable way to collect information, knowledge, and guidance towards action. The challenge is so complex to force corporations and educational institutions in this regard, community college programs to adapt to the realities of the industrial world are 
currently cooperating, and that's why training must be extra important to modern educational programs along with an internship at a company.

Adequate education and training needed to prepare employees entering the work environment particularly in the era of digitalization that advanced quickly. The factories engaged in manufacturing should be able to offer the appropriate environmental conditions to combine theoretical learning and practical application for new employees(Anton \& Shikov, 2018; Görke, Bellmann, Busch, \& Nyhuis, 2017) or the old employees in adding his ability(Connor, 2010), therefore the bid or the Corporation is required to deliver the knowledge and skills(Payne, 2008) of the Industry in accordance with the latest technological advances. The training provided should include the relevant elements needed by employees of new or old in the travel help industry find solutions manual to automatic very good.

Training and development with the use of a dual system is an innovative model(Lewis, 2007), this model is intended to combine as well as instilling an understanding between theoretical and practical education centers, collaboration between the companies and institutions adapted to the needs of the ability and competence of the community in entering the world of work. The participants of the training programs and the development of a dual system have the opportunity(Juul \& Jørgensen, 2011) to learn in a real environment more real in the company, promoting the conceptual and procedural training programs given to improve the ability of pedagogy in entering the world of work in the real industry.

Training and development corporations to Community competence and community skills, with instilling an understanding between theoretical and practical education centers, community development programs is the collaboration between companies and institutions adapted to the needs of the industry will enter the workforce capability in desperate need of skill and competence(Soakell-Ho \& Myers, 2011; Wademan, Spuches, \& Doughty, 2010).

\section{STRATEGIC TRAINING AND DEVELOPMENT OF STAKEHOLDER PARTICIPATION}

Community development must be with the involvement of the community itself, community involvement is a major component of Corporate Social Responsibility (CSR)(Boadi, He, Darko, \& Abrokwah, 2018). This can be achieved through philanthropy, as well as development projects and social investment. Community training and development requires a better understanding of various community expectations and allows citizens to become more involved in the decision-making process(Breeman, Termeer, \& Lieshout, 2013). Community involvement and development(Kumazawa \& Nakamura, 2010) can be improved by paying attention to social licenses to operate and by adopting a more proactive approach.

Training and development in a community are useful contextually and effectively in evaluating educational programs carried out by an institution, where the results of this training program are to handle the availability of human resources to be placed in companies and the most important is ensuring that there is involvement of all stakeholders in the program prepared. The use of the community readiness model to develop and evaluate training programs will get: (1) increasing overall awareness, (2) increasing the dimension of knowledge, (3) having leadership, (4) knowing the problems faced and (5) knowing barriers, leadership, and motivation.

Community involvement for sustainable development must ensure the involvement of the community itself, where community involvement is community participation as a development stakeholder. Factors that influence community-based development management(P. Chen, Lee, Lin, \& Zhang, 2016) include the knowledge of the community about the environment, the 
motivation to be involved in development, the perceived economic impact, the perception of social and cultural impacts and positive community participation.

A work environment that increasingly requires technological mastery and is more competitive in the economic field requires that people who will enter the workforce, especially in industry, have appropriate understanding, skills and technical knowledge. The strategic role of training and development for new employees or old employees is to prepare the community to be able to have the required competencies, knowledge and skills. The rationale for policy interests in career development services for old employees or prospective new workers(Kornblum, Unger, \& Grote, 2018) with the current transformation in work and career that requires the attention of all stakeholders. The structure and process is needed to bring together career development practitioners with policymakers and the interests of other stakeholders to handle tasks of common concern.

The development of knowledge about technology by optimizing project management through special training for all stakeholders will determine significantly the quality of managers, the ability to manage and support of top management in technology development. Where the three factors have a very significant influence on training and project development. The main objective of the training and development program is to harmonize employee expertise with organizational goals. Organizations can achieve desired goals only when employees are able to transfer the skills learned at work. The stakeholders must manage training programs effectively. The transfer of knowledge and competencies obtained in training must be maximized, this will be realized when the trainees have social support, high performance, and good motivation. Stakeholders are important for the training transfer process, such as student readiness, trainee reaction, and training retention.

\section{STRATEGIC TRAINING AND DEVELOPMENT TOWARDS COMMUNITY EMPOWERMENT}

Trainers and employee development should not only provide skills to old employees or prospective new workers but also the most important thing is to be able to improve their competencies(Tsai, 2015) to solve problems when working in the industry, so with training and development, these employees will take part in community college programs. Demanded to be able to understand and be able to work in accordance with the targets provided by the industry based on their capabilities(J. J. Oliver, 2017). The success of an industrial corporation depends on how competitive employees can produce goods for customer satisfaction with competitive prices and giving time. Furthermore, the manufacturing process has a number of steps to ensure that the product conforms to the requirements that always change customers.

Learning to the community must be seen as a supportive capacity for the realization and management of community empowerment programs(Cho \& De Moya, 2016; Lawson, 2005), and used as program development in the future. Whereas the role of the community as a target can be seen in the level of community participation in participating in various programs related to improving their skills, abilities, and quality so that they can improve the social welfare of the poor in the area to be more empowered. Training and development carried out by industrial corporations(Gospel \& Edwards, 2012; Kim, 2005), is a type of non-formal education which is not only for building previous formal education from a small proportion of its citizens but more specifically to increase the economic and social level of most of its citizens.

The influence of training and development on the empowerment of people who have a weak economic background, so that life skills acquired from the training are only limited to experience and have not reached the level of improving community welfare. The education and 
training programs to empower the community in the form of non-formal activities carried out by corporations have not been able to increase people's income, especially to the level of their welfare.

\section{CONCLUSION}

Regardless of the method used, the content of training and development activities must be designed to maximize learning. The principles that must be considered are clear instructions, such as appropriate behavior, active participation, reinforcement, criticism or input. An examination of the work environment is also important to ensure that new behavior will be maintained by setting goals for subsequent performance and ensuring that improvements in work are strengthened again.

\section{FUNDING}

This research received no external funding.

\section{CONFLICTS OF INTEREST}

The author declares no conflict of interest.

\section{References}

Adjei, E., \& Mensah, M. (2016). Adopting total quality management to enhance service delivery in medical records: Exploring the case of the Korle-Bu Teaching Hospital in Ghana. Records Management Journal, 26(2), 140-169. https://doi.org/10.1108/RMJ-01-2015-0009

Ameh, C. A., Kerr, R., Madaj, B., Mdegela, M., Kana, T., Jones, S., ... Van Den Broek, N. (2016). Knowledge and skills of healthcare providers in sub-Saharan Africa and Asia before and after competency-based training in emergency obstetric and early Newborn Care. PLoS ONE, 11(12), 1-15. https://doi.org/10.1371/journal.pone.0167270

Ameh, C. A., White, S., Dickinson, F., Mdegela, M., Madaj, B., \& Van Den Broek, N. (2018). Retention of knowledge and skills after Emergency Obstetric Care training: A multicountry longitudinal study. PLoS ONE, 13(10), 1-13. https://doi.org/10.1371/journal.pone.0203606

Anton, C., \& Shikov, A. (2018). The method of personalized corporate e-learning based on personal traits of employees. Procedia Computer Science, 136, 511-521. https://doi.org/10.1016/j.procs.2018.08.253

Anwaruddin, S. M. (2015). Teacher professional learning in online communities: toward existentially reflective practice. Reflective Practice, 16(6), 806-820. https://doi.org/10.1080/14623943.2015.1095730

Astakhova, L. V. (2017). The information-and-cognitive activities of a person in a knowledge-based society. Scientific and Technical Information Processing, 43(4), 251-256. https://doi.org/10.3103/s0147688216040055

Atitumpong, A., \& Badir, Y. F. (2018). Leader-member exchange, learning orientation and innovative work behavior. Journal of Workplace Learning, 30(1), 32-47. https://doi.org/10.1108/JWL-01-2017-0005

Badura, P., Sigmund, E., Geckova, A. M., Sigmundova, D., Sirucek, J., Van Dijk, J. P., \& Reijneveld, S. A. (2016). Is participation in organized leisure-time activities associated with school performance in adolescence? PLoS ONE, 11(4), 1-14. https://doi.org/10.1371/journal.pone.0153276

Bauerle, T., Brnich, M. J., \& Navoyski, J. (2016). Exploring virtual mental practice in maintenance task training. Journal of Workplace Learning, 28(5), 294-306. https://doi.org/10.1108/JWL-10-2015-0078

Bennett, J., Tognolini, J., \& Pickering, S. (2012). Establishing and applying performance standards for curriculumbased examinations. Assessment in Education: Principles, Policy and Practice, 19(3), 321-339.

https://doi.org/10.1080/0969594X.2011.614219

Boadi, E. A., He, Z., Darko, D. F., \& Abrokwah, E. (2018). Unlocking from Community Stakeholders, Corporate Social Responsibility (CSR) projects for effective Company-Community relationship. Labor History, 59(6), 746-762. https://doi.org/10.1080/0023656X.2018.1470223

Breeman, G., Termeer, C. J. A. M., \& Lieshout, M. Van. (2013). Decision making on mega stables: Understanding and preventing citizens' distrust. NJAS - Wageningen Journal of Life Sciences, 66, 39-47.

https://doi.org/10.1016/j.njas.2013.05.004

Charles Catania, A. (2017). The nonmaintenance of behavior by noncontingent reinforcement. European Journal of Behavior Analysis, 6(1), 89-94. https://doi.org/10.1080/15021149.2005.11434253 
Darmawi, A., Darsono., Kartono, D. T., \& Anantanyu, S. (2019). Educational Model Study to Train and Develop Competitive Workers, Based on Learning Objectives. Advances in Social Sciences Research Journal, 6(5) 1-14.

Chen, P., Lee, C. Di, Lin, H., \& Zhang, C. X. (2016). Factors that develop effective professional learning communities in Taiwan. Asia Pacific Journal of Education, 36(2), 248-265. https://doi.org/10.1080/02188791.2016.1148853

Chen, R., Huang, Y., Wu, T., Zhao, Y., Wang, B., \& Guo, A. (2014). General Practice On-the-Job Training in Chinese Urban Community: A Qualitative Study on Needs and Challenges. PLoS ONE, 9(4), e94301.

https://doi.org/10.1371/journal.pone.0094301

Cho, M., \& De Moya, M. (2016). Empowerment as a Key Construct for Understanding Corporate Community Engagement. International Journal of Strategic Communication, 10(4), 272-288.

https://doi.org/10.1080/1553118X.2016.1144606

Chua, E. F., Hannula, D. E., \& Ranganath, C. (2012). Distinguishing highly confident accurate and inaccurate memory: Insights about relevant and irrelevant influences on memory confidence. Memory, 20(1), 48-62. https://doi.org/10.1080/09658211.2011.633919

Chukwuere, J. (2018). The application of a culture-oriented e-learning system framework for developers : an approach for developing countries. Journal of Gender, Information and Development in Africa, 7(2), 9-37. https://doi.org/10.31920/2050-4284/2018/v7n2a1

Cohn, M. A., \& Fredrickson, B. L. (2010). In search of durable positive psychology interventions: Predictors and consequences of long-term positive behavior change. Journal of Positive Psychology, 5(5), 355-366. https://doi.org/10.1080/17439760.2010.508883

Connor, S. (2010). Promoting "Employ ability": The changing subject of welfare reform in the UK. Critical Discourse Studies, 7(1), 41-54. https://doi.org/10.1080/17405900903453930

Copella, J., \& Sireci, S. G. (2013). Review of Cutscores: A Manual for Setting Standards of Performance on Educational and Occupational Tests . Applied Measurement in Education, 26(1), 73-76. https://doi.org/10.1080/08957347.2013.739462

Covarrubias Venegas, B., \& Thill, K. (2015). Towards a New Competency Model for Hrm . the Art of Competency Modelling - a New Approach for Hrm. International Journal of Arts \& Sciences, 8(5), 597-621.

Dasgupta, S. A., Suar, D., \& Singh, S. (2014). Managerial communication practices and employees' attitudes and behaviours : A qualitative study. Corporate Communications, 19(3), 287-302. https://doi.org/10.1108/CCIJ-042013-0023

Daszuta, W., \& Ghosh, S. (2018). Risk management on offshore vessels: training, expectations and reality. Australian Journal of Maritime \& Ocean Affairs, 10(3), 168-181. https://doi.org/10.1080/18366503.2018.1486065

De Vos, A., Dewettinck, K., \& Buyens, D. (2009). The professional career on the right track: A study on the interaction between career self-management and organizational career management in explaining employee outcomes. European Journal of Work and Organizational Psychology, 18(1), 55-80. https://doi.org/10.1080/13594320801966257

Dewaele, J. M. (2019). Multilingualism and trait emotional intelligence: an exploratory investigation. International Journal of Multilingualism, O(0), 1-15. https://doi.org/10.1080/14790718.2019.1571065

Diaz-Vilela, L. F., Rodriguez, N. D., Isla-Diaz, R., Diaz-Cabrera, D., Hernández-Fernaud, E., \& Rosales-Sánchez, C. (2015). Relationships between contextual and task performance and interrater agreement: Are there any? PLoS ONE, 10(10), 1-14. https://doi.org/10.1371/journal.pone.0139898

Erlandsson, A., Nilsson, A., \& Västfjäll, D. (2018). Attitudes and Donation Behavior When Reading Positive and Negative Charity Appeals. Journal of Nonprofit and Public Sector Marketing, 30(4), 444-474.

https://doi.org/10.1080/10495142.2018.1452828

Field, L. (2011). Exploring the political underbelly of organizational learning: Learning during pay and performance management change. The Learning Organization, 18(4), 272-287.

https://doi.org/10.1108/09696471111132496

FLOREA, N. V., \& MIHAI, D. C. (2017). Predicting Employees Evaluation Performance Using Simulation and Mathematical Modeling. Journal of Science \& Arts, 17(1), 81-94. Retrieved from http://proxy.lib.ohiostate.edu/login?url=http://search.ebscohost.com/login.aspx?direct=true \&db=a9h\&AN=122574199\&site=ehostlive

Flores, S. A., Liew, J., Miner, K., Bench, S. W., \& Lench, H. C. (2015). Gender Gaps in Overestimation of Math Performance. Sex Roles, 72(11-12), 536-546. https://doi.org/10.1007/s11199-015-0486-9 
Fong, R. W., Lau, P. S. Y., Lee, Q., Yuen, M., Gysbers, N. C., Shea, P. M. K., ... Chung, Y. B. (2010). Enhancing life skills development: Chinese adolescents' perceptions. Pastoral Care in Education, 28(4), 295-310. https://doi.org/10.1080/02643944.2010.528015

Forsblom, L., Negrini, L., Gurtner, J. L., \& Schumann, S. (2016). Dropouts in Swiss vocational education and the effect of training companies' trainee selection methods. Journal of Vocational Education and Training, 68(4), 399415. https://doi.org/10.1080/13636820.2016.1222596

Fraser-Arnott, M. (2017). Competencies for information specialists in emerging roles. Library Management, 38(1), 65-76. https://doi.org/10.1108/LM-09-2016-0074

Gorgievski, M. J., Bakker, A. B., \& Schaufeli, W. B. (2010). Work engagement and workaholism: Comparing the selfemployed and salaried employees. Journal of Positive Psychology, 5(1), 83-96.

https://doi.org/10.1080/17439760903509606

Görke, M., Bellmann, V., Busch, J., \& Nyhuis, P. (2017). Employee Qualification by Digital Learning Games. Procedia Manufacturing, 9, 229-237. https://doi.org/10.1016/j.promfg.2017.04.040

Gospel, H., \& Edwards, T. (2012). Strategic transformation and muddling through: industrial relations and industrial training in the UK. Journal of European Public Policy, 19(8), 1229-1248.

https://doi.org/10.1080/13501763.2012.709023

Grambow, S. C., Perkins, S. M., Pollock, B. H., Oster, R. A., Benn, E. K. T., Rahbar, M. H., ... Carter, R. E. (2017). Statistical competencies for medical research learners: What is fundamental? Journal of Clinical and Translational Science, 1(3), 146-152. https://doi.org/10.1017/cts.2016.31

Grover, K. S., \& Miller, M. T. (2019). Issues Facing Community College Job Training Programs: A Delphi Approach. The Journal of Continuing Higher Education, 66(3), 170-175. https://doi.org/10.1080/07377363.2018.1525523

Gupta, D., Mehta, M., \& Sagar, R. (2015). Interpersonal skills. A Practical Approach to Cognitive Behaviour Therapy for Adolescents, 2820(2007), 91-107. https://doi.org/10.1007/978-81-322-2241-5_5

Hall, M. R., \& Hall, M. R. (2009). Corporate Philanthropy and Corporate Community Relations : Measuring Relationship-Building Results Corporate Philanthropy and Corporate Community Relations : Measuring Relationship-Building Results. Journal of Public Relations Research, (July 2015). https://doi.org/10.1207/s1532754xjprr1801

Heaysman, O., \& Tubin, D. (2018). Content teaching: innovative and traditional practices. Educational Studies, 5698, 1-15. https://doi.org/10.1080/03055698.2018.1446334

Hubert, J., Vrij, A., Horselenberg, R., van Koppen, P., \& Adams-Quackenbush, N. M. (2019). Interview expectancies: awareness of potential biases influences behaviour in interviewees. Psychiatry, Psychology and Law, 0(0), 1-17. https://doi.org/10.1080/13218719.2018.1485522

Ibenne, S. K., Simeonova, B., \& Harrison, J. (2017). An integrated model highlighting information literacy and knowledge formation in information behaviour. Aslib Journal of Information Management, 69(3), 316-334. https://doi.org/10.1108/AJIM-09-2016-0148

Jan, S. U., \& Anwar, M. A. (2019). Emotional Intelligence, Library use, and Academic Achievement of University Students. Journal of the Australian Library and Information Association, 0(0), 1-18. https://doi.org/10.1080/24750158.2019.1572482

Jeffrey, S. A., \& Adomdza, G. K. (2011). Incentive salience and improved performance. Human Performance, 24(1), 47-59. https://doi.org/10.1080/08959285.2010.530631

Jung*, I. (2005). Cost-effectiveness of online teacher training. Open Learning: The Journal of Open, Distance and ELearning, 20(2), 131-146. https://doi.org/10.1080/02680510500094140

Juul, I., \& Jørgensen, C. H. (2011). Challenges for the dual system and occupational self-governance in Denmark. Journal of Vocational Education and Training, 63(3), 289-303. https://doi.org/10.1080/13636820.2011.560393

Kang, M., \& Sung, M. (2017). How symmetrical employee communication leads to employee engagement and positive employee communication behaviors: The mediation of employee-organization relationships. Journal of Communication Management, 21(1), 82-102. https://doi.org/10.1108/JCOM-04-2016-0026

Kim, C. K. (2005). An industrial development strategy for Indonesia: Lessons from the South Korean experience. Journal of the Asia Pacific Economy, 10(3), 312-338. https://doi.org/10.1080/13547860500163589

Koch, M., \& Fritz, M. (2013). Non-Standard Employment in Europe. Paradigms, Prevalence and Policy Responses [Work and Welfare in Europe]. International Review of Social History, 246.

https://doi.org/10.1017/S0020859015000280 
Darmawi, A., Darsono., Kartono, D. T., \& Anantanyu, S. (2019). Educational Model Study to Train and Develop Competitive Workers, Based on Learning Objectives. Advances in Social Sciences Research Journal, 6(5) 1-14.

Komulainen, T. M., \& Sannerud, A. R. (2018). Learning transfer through industrial simulator training: Petroleum industry case. Cogent Education, 5(1), 1-19. https://doi.org/10.1080/2331186X.2018.1554790

Kont, K. R., \& Jantson, S. (2014). Organization of work in Estonian university libraries: A review and survey. New Library World, 115(9-10), 452-470. https://doi.org/10.1108/NLW-02-2014-0020

Kornblum, A., Unger, D., \& Grote, G. (2018). When do employees cross boundaries? Individual and contextual determinants of career mobility. European Journal of Work and Organizational Psychology, 27(5), 657-668. https://doi.org/10.1080/1359432X.2018.1488686

Kruse, J. W., \& Wilcox, J. L. (2015). Engaging Students with the Nature of Science and the Nature of Technology by Modeling the Work of Scientists. The Clearing House: A Journal of Educational Strategies, Issues and Ideas, 86(3), 109-115. https://doi.org/10.1080/00098655.2013.772888

Kumazawa, T., \& Nakamura, Y. (2010). Personal Involvement of Residents and Development Strategies in a Community Planning. Journal of Asian Architecture and Building Engineering, 2(1), 147-151.

https://doi.org/10.3130/jaabe.2.147

Lam, R. (2017). Enacting feedback utilization from a task-specific perspective. Curriculum Journal, 28(2), 266-282. https://doi.org/10.1080/09585176.2016.1187185

Lawson, H. A. (2005). Empowering people, facilitating community development, and contributing to sustainable development: The social work of sport, exercise, and physical education programs. Sport, Education and Society, 10(1), 135-160. https://doi.org/10.1080/1357332052000308800

Lee, C. K.-E., Lim, T.-K., \& Ng, M. (2008). Affective Outcomes of Cooperative Learning in Social Studies. Asia Pacific Journal of Education, 17(1), 67-75. https://doi.org/10.1080/02188799708547744

Lewiński, M. (2017). Collective Argumentative Criticism in Informal Online Discussion Forums. Argumentation and Advocacy, 47(2), 86-105. https://doi.org/10.1080/00028533.2010.11821740

Lewis, T. (2007). The problem of cultural fit - What can we learn from borrowing the German Dual System? Compare, 37(4), 463-477. https://doi.org/10.1080/03057920701366408

Lin, Y. (2005). The grim situation in China with regard to building a teacher base and rejuvenating the higher education system. Chinese Education and Society, 38(5), 31-37. https://doi.org/10.1016/j.tca.2004.12.008

Lukuyu, B., Place, F., Franzel, S., \& Kiptot, E. (2012). Disseminating Improved Practices: Are Volunteer Farmer Trainers Effective? Journal of Agricultural Education and Extension, 18(5), 525-540.

https://doi.org/10.1080/1389224X.2012.707066

Marinescu, P., \& Toma, S. G. (2013). Training Programs - Training and Development Alternatives for Students. Procedia Economics and Finance, 6(13), 306-312. https://doi.org/10.1016/s2212-5671(13)00144-5

Marjoribanks, K. (2006). Adolescents' cognitive habitus, learning environments, affective outcomes of schooling, and young adults' educational attainment. Educational Psychology, 26(2), 229-250.

https://doi.org/10.1080/01443410500344233

Marlos Varonis, E. (2014). Most courses are not born digital. Campus-Wide Information Systems, 31(4), 217-229. https://doi.org/10.1108/cwis-09-2013-0053

Marlow, M. L. (2016). Speech criticism, face-work, and communication responses: Towards a model of speech criticism and feedback. Journal of Multicultural Discourses, 11(4), 389-411.

https://doi.org/10.1080/17447143.2016.1250767

Martinez, S. L. (2014). Training Tech Services' Student Employees Well: Evidence-based Training Techniques in Conjunction with Coaching and Mentoring Strategies. Cataloging and Classification Quarterly, 52(5), 551-561. https://doi.org/10.1080/01639374.2014.903548

Masset, E., \& Haddad, L. (2015). Does beneficiary farmer feedback improve project performance? An impact study of a participatory monitoring intervention in Mindanao, Philippines. Journal of Development Studies, 51(3), 287304. https://doi.org/10.1080/00220388.2014.959933

McCarley, J. S., Irwin, D. E., Peterson, M. S., Wang, R. F., Boot, W. R., \& Kramer, A. F. (2006). Oculomotor behaviour in visual search for multiple targets. Visual Cognition, 14(4-8), 685-703.

https://doi.org/10.1080/13506280500194147

Moyo, C. S. (2014). Active Participation of Rural Women in Developmental Issues : Poverty Alleviation Lessons for South Africa. Gender and Bahaviour, 12(1), 5994-6001. 
Nissim, G., \& De Vries, D. (2014). Permanent liminality: The impact of non-standard forms of employment on workers' committees in Israel. International Labour Review, 153(3), 435-454. https://doi.org/10.1111/j.1564913X.2014.00010.x

Oliver, G. R., Lynch, C. D., Chadwick, B. L., Santini, A., \& Wilson, N. H. F. (2016). What i wish I'd learned at dental school. British Dental Journal, 221(4), 187-194. https://doi.org/10.1038/sj.bdj.2016.602

Oliver, J. J. (2017). Exploring industry level capabilities in the U.K. creative industries. Creative Industries Journal, 10(1), 75-88. https://doi.org/10.1080/17510694.2017.1282302

Olokundun, M., Falola, H., Salau, O., ibidunni, S., Peter, F., \& Borishade, T. (2018). Data set on the effect of training and development on creativity of academic staff in a selected Nigerian university. Data in Brief, 18, 399-403. https://doi.org/10.1016/j.dib.2018.03.025

Payne, J. (2008). Sector skills councils and employer engagement - Delivering the "employer-led" skills agenda in England. Journal of Education and Work, 21(2), 93-113. https://doi.org/10.1080/13639080802090260

Poell, R. F., \& Van Der Krogt, F. (2017). Why is organizing human resource development so problematic?: Perspectives from the learning-network theory (Part II). Learning Organization, 24(4), 215-225. https://doi.org/10.1108/TLO-12-2016-0094

Pomohaci, M. (2016). the Importance of Socialization Through Sport in Students Group Integration. SocialBehavioural Science, 2(2), 151-160.

Rangriz, H., \& Pashootanizadeh, H. (2014). Desirable System Requirements for Employee Performance Evaluation to Establishment of Meritocracy and Continuous Improvement by using TQMPE and AHP Model. Science, Technology and Arts Research Journal, 3(3), 185. https://doi.org/10.4314/star.v3i3.30

Rasmussen, D., Voelker, A., \& Eliasmith, C. (2017). A neural model of hierarchical reinforcement learning. PLoS ONE (Vol. 12). https://doi.org/10.1371/journal.pone.0180234

Ray, M., Milston, A., Doherty, P., \& Crean, S. (2017). How prepared are foundation dentists in England and Wales for independent general dental practice? British Dental Journal, 223(5), 359-368.

https://doi.org/10.1038/sj.bdj.2017.766

Richey, J. E., Bernacki, M. L., Belenky, D. M., \& Nokes-Malach, T. J. (2018). Comparing Class- and Task-Level Measures of Achievement Goals. Journal of Experimental Education, 86(4), 560-578. https://doi.org/10.1080/00220973.2017.1386155

Sack, F. (2012). Gen green: Changes in Australian apprentices' and trainees' experience of skills and sustainability from 2008 to 2011. International Journal of Training Research, 10(1), 30-42.

https://doi.org/10.5172/ijtr.2012.10.1.30

Sanli, E., Ennis, K. A., Brown, R., \& Carnahan, H. (2018). The development and validation of key performance indicators for two tasks related to Marine Emergency Duties training. International Journal of Training Research, 16(2), 145-154. https://doi.org/10.1080/14480220.2018.1501911

Scott, S. E., Cortina, K. S., \& Carlisle, J. F. (2012). Understanding Coach-Based Professional Development in Reading First: How do Coaches Spend Their Time and How do Teachers Perceive Coaches' Work? Literacy Research and Instruction, 51(1), 68-85. https://doi.org/10.1080/19388071.2011.569845

Seyfried, M., \& Pohlenz, P. (2018). Assessing quality assurance in higher education: quality managers' perceptions of effectiveness. European Journal of Higher Education, 8(3), 258-271.

https://doi.org/10.1080/21568235.2018.1474777

Smith, E. (2002). Theory and practice: The contribution of off-the-job training to the development of apprentices and trainees. Journal of Vocational Education and Training, 54(3), 431-456.

https://doi.org/10.1080/13636820200200208

Soakell-Ho, M., \& Myers, M. D. (2011). Knowledge management challenges for nongovernment organizations. Vine, 41(2), 212-228. https://doi.org/10.1108/03055721111134826

Sofiadin, A. binti M. (2014). Sustainable development, e-learning and Web 3.0: A descriptive literature review. Journal of Information, Communication and Ethics in Society, 12(3), 157-176. https://doi.org/10.1108/JICES-032014-0018

Thompson, R., \& Russell, L. (2017). Trainee teachers in unpaid teaching posts: volunteering, risk and vulnerability. Journal of Vocational Education and Training, 69(4), 637-654. https://doi.org/10.1080/13636820.2017.1322129 
Tomažič, I., Hummel, E., Schrenk, M., Rupnik, T., \& Randler, C. (2018). Cognitive and affective outcomes of teaching about poisonous and venomous animals. Journal of Biological Education, 0(0), 1-14. https://doi.org/10.1080/00219266.2018.1546757

Tomozeiu, D., \& Kumpulainen, M. (2016). Operationalising intercultural competence for translation pedagogy. Interpreter and Translator Trainer, 10(3), 268-284. https://doi.org/10.1080/1750399X.2016.1236558

Tripathi, K., \& Borrion, H. (2016). Safe, secure or punctual A simulator study of train driver response to reports of explosives on a metro train. Security Journal, 29(1), 87-105. https://doi.org/10.1057/sj.2015.46

Tsai, C. Y. (2015). Improving Students' PISA Scientific Competencies Through Online Argumentation. International Journal of Science Education, 37(2), 321-339. https://doi.org/10.1080/09500693.2014.987712

van der Post, D. J., de Weerd, H., Verbrugge, R., \& Hemelrijk, C. K. (2013). A Novel Mechanism for a Survival Advantage of Vigilant Individuals in Groups. The American Naturalist, 182(5), 682-688.

https://doi.org/10.1086/673298

van Dyk, L., \& Fourie, L. (2012). Towards contextualising stakeholder relationship indicators for corporatecommunity relationships. Communicatio, 38(3), 349-364. https://doi.org/10.1080/02500167.2012.723633

Van Looy, L., \& Goegebeur, W. (2007). Teachers and teacher trainees as classroom researchers: Beyond Utopia? Educational Action Research, 15(1), 107-126. https://doi.org/10.1080/09650790601151384

Wademan, M. R., Spuches, C. M., \& Doughty, P. L. (2010). The People Capability Maturity Model. Performance Improvement Quarterly, 20(1), 97-123. https://doi.org/10.1111/j.1937-8327.2007.tb00434.x

Wang, Y. Y., Lin, T. C., \& Tsay, C. H. H. (2016). Encouraging IS developers to learn business skills: an examination of the MARS model. Information Technology and People, 29(2), 381-418. https://doi.org/10.1108/ITP-02-20140044

Whiteside, A. L., Garrett Dikkers, A., \& Lewis, S. (2017). "More Confident Going into College" : Lessons Learned from Multiple Stakeholders in a New Blended Learning Initiative. Online Learning, 20(4), 136-157. https://doi.org/10.24059/olj.v20i4.1048

Wolff, F. C. (2015). Do the Return Intentions of French Migrants Affect Their Transfer Behaviour? Journal of Development Studies, 51(10), 1358-1373. https://doi.org/10.1080/00220388.2015.1046443

Wongnaa, C. A., \& Boachie, W. K. (2018). Perception and adoption of competency-based training by academics in Ghana. International Journal of STEM Education, 5(1). https://doi.org/10.1186/s40594-018-0148-x

Wubbels, T., Brok, P. Den, Veldman, I., \& Van Tartwijk, J. (2006). Teacher interpersonal competence for Dutch secondary multicultural classrooms. Teachers and Teaching: Theory and Practice, 12(4), 407-433. https://doi.org/10.1080/13450600600644269

Ye, E., Ye, X., \& Liu, C. (2018). TeamWATCH: Visualizing development activities using a 3-D city metaphor to improve conflict detection and team awareness. PLOS ONE, 13(3), 1-28.

https://doi.org/10.1371/journal.pone.0193562

Zumrah, A. R. (2015). How to enhance the impact of training on service quality?: Evidence from Malaysian public sector context. Journal of Workplace Learning, 27(7), 514-529. https://doi.org/10.1108/JWL-06-2014-0048 